From Nursery Rhymes to Nationhood: Children's Literature and the Construction of Canadian Identity. By Elizabeth A. Galway. (New York and London: Routledge, 2008. Pp. $1+196$, notes, selected bibliography, index.)

JON D. LEe

Focusing on children's literature from the late $19^{\text {th }}$ and early $20^{\text {th }}$ centuries, From Nursery Rhymes to Nationhood provides scholars of folklore, literature and history with a much-needed text that examines the role children's literature played in forming Canadian national identity. As a whole, the book is well-written and free of academic jargon, and Galway, using 115 primary sources (i.e. $19^{\text {th }}$ and $20^{\text {th }}$ century children's literature) and at least twice as many secondary sources (largely contemporary academic texts from various disciplines, including history and English), details well the many themes and ideals that permeated children's literature in this formative era.

Galway argues that literature provides a source for ongoing contemplation of identity and that children's literature plays a crucial role in their own understanding of belonging and difference. She examines how the books and stories of the age dealt with questions of loyalty, differing in their opinions about whether Canadians should remain faithful to the British Empire, show greater political and cultural alignment with the United States, or attempt to establish themselves as independent of both. Next, Galway demonstrates how, on the basis of these three alternatives, authors proposed varying ideas for how to best construct a national identity, some attempting to do so on "a racial or ethnic basis" that placed dividers among Anglophones, Francophones, and First Nations people and others adopting a "biracial, bilingual system" free of hierarchies (175). Finally, she establishes that the literature was also attempting to formulate national values like pacifism, environmental concern and freedom, around which Canadian citizens could unite.

As Galway proves, the problems associated with the struggle between belonging and differentiation are numerous and varied. Some of these problems were overt, such as questions relating to which country Canadians should remain loyal, or indecision concerning how "Indians" should be represented in storiesas "noble savages," as unmitigated protagonists, or (as was unfortunately less common) as equals. Paraphrasing Canadian children's literature critic Roderick McGillis, Galway notes that the treatment of First Nations people functioned "as a means of negotiating the boundary between 'self' and 'other," a debate that helped structure "who and what the Canadian identity should represent" (114). Another debated issue was the fact that much of the children's literature available at the time was published not in Canada, but in Britain or the United States, and was often written by citizens of those countries.

As post-Confederation Canada struggled to form a national identity separate from that of England, children's literature increasingly featured Canadian, English, and American children interacting, with Canadian children having to instruct or rescue their foreign friends. For example, in The Captain of the Club, a novel from 1889 that Galway references frequently, the author presents Canadian children 
as "physically superior to their American counterparts" at canoeing (68) and instinctively aware of landscape as "a source of pride" (159) as they teach their friends about the benefits of interacting positively with nature.

Galway makes a valuable contribution to the study of children's literature as a source of debates on identity and nation-building. As she traces these arguments Galway maintains an intelligent, objective, and insightful commentary. The scholarship is impressive for its coherent synthesis of a wide scope of data, resulting in a text that should be easily accessible to undergraduates. Indeed, a class on children's literature in Canada would be remiss not to assign this as a textbook, so valuable are the ideas presented here. The book is not without its small faults, however, and there are some sections where data could have been better organized. For instance, page twelve of the introduction lists the assassination of Louis Real, the Boer War of 1899, and the 1903 Alaska Boundary Question as important historical points in the development of children's literature. However, these events receive no elaboration until pages thirty-eight, forty-six, and fifty-five, respectively, and there is no notice in the introduction that these elaborations are forthcoming. It would be easy for readers-especially if they are unfamiliar with this era of Canadian history-to glean from such an introduction that the book assumes a far greater comprehension than it actually does. Still, such faults are relatively minor, and are few in number. Overall, the text is exceedingly well-organized and lucid. Though the book focuses only on Canadian children's literature of a specific period, it should be required reading for students of any aspect of children's literature, regardless of concentration. The lessons learned in these pages about the importance of literature for national identity would be well emphasized in other works, and Galway provides an excellent and attentionworthy method of analysis and discussion. The book is a wonderful and valuable contribution to the field.

Haunted Halls: Ghostlore of American College Campuses. By Elizabeth Tucker. (Jackson: University Press of Mississippi, 2007. Pp. vii + 241, illustrations, references, index.)

\section{JODI MCDAVID}

Haunted Halls is a unique approach to the somewhat familiar subject matter of campus legends. Elizabeth Tucker, a professor of English at Binghamton University, comes to this material through an interesting set of circumstances; she has been Faculty Master of a residential community on the Binghamton campus for a number of years. Her experience as a folklorist and residence coordinator creates a unique viewpoint for this readable and academically grounded book.

Haunted Halls straddles the line between legend collection and analytic text quite well, providing tale type and motif index references for many of the narratives. The chapters all stand well on their own, due in part to some of their previous lives as articles which have been edited for the current publication. Four chapters draw on articles which were published elsewhere. Tucker links legends thematically across campuses, for example, finding "Wailing Women" at a variety 